\title{
Total Synthesis of Piericidin A1 and B1
}

\author{
Martin J. Schnermann and Dale L. Boger \\ Department of Chemistry and The Skaggs Institute for Chemical Biology, The Scripps Research \\ Institute, 10550 N. Torrey Pines Road, La Jolla, California 92037, E-mail: boger@scripps.edu
}

\begin{abstract}
The first total syntheses of piericidin A1 and B1 are disclosed and unambigously establish the relative and absolute stereochemistry of the natural products by an approach that will facilitate the synthesis of a series of analogues. Central to the approach is an inverse electron demand Diels-Alder reaction of a $N$-sulfonyl-1-aza-1,3-butadiene with tetramethoxyethene followed by Lewis acid-promoted aromatization used to assemble the functionalized pyridine core. Additional key elements in the convergent approach include the use of an anti-aldol reaction to install the $\mathrm{C} 9$ and $\mathrm{C} 10$ relative and absolute stereochemistry, a modified Julia olefination for formation of the $\mathrm{C} 5-\mathrm{C} 6$ trans double bond with convergent assemblage of the side chain, and a penultimate heterobenzylic Stille cross-coupling reaction of the pyridyl core with the fully elaborated side chain.
\end{abstract}

The piericidins are an important class of biologically active natural products isolated from Streptomyces mobaraensis and pactam of which piericidin A1 (1) is the prototypical member. ${ }^{1}$ Piericidin A1 is one of the most potent inhibitors of the mitochondrial electron transport chain protein NADH-ubiquinone reductase (complex I, $K_{\mathrm{i}}=0.6-1.0 \mathrm{nM}$ ) defined to date, and has contributed extensively to the elucidation of the enzyme properties. ${ }^{1}$ It has been suggested that the 4-hydroxypyridine of $\mathbf{1}$ (as the pyridone tautomer) mimics the quinone of ubquinone (coenzyme Q, 3) with the side chain of $\mathbf{1}$ mimicking the prenyl chain and this apparent structural relationship was confirmed through their competitive binding against complex I. ${ }^{2-4}$

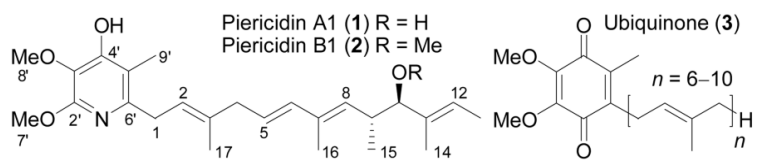

Despite an array of additional important biological activity, no total synthesis of a member of this now large class of natural products has been disclosed. In efforts directed at this family, the preparation of the fully elaborated pyridine ring system substituted with simplified side chains has been reported, ${ }^{5}$ as well as an asymmetric synthesis of the C6-C13 segment of the side chain bearing the most recent stereochemical assignment $(9 R, 10 R) .{ }^{6}$ Notably, the originally assigned absolute stereochemistry ${ }^{7}$ of the side chain substituents of $\mathbf{1}$ has been challenged, reassigned, and remained to be determined. ${ }^{8,9}$

Herein we detail the first total synthesis of piericidin A1 and B1 by an approach that establishes the absolute stereochemistry of the natural products and will facilitate the synthesis of a series of key analogues. Central to the approach is an inverse electron demand Diels-Alder reaction between a $N$-sulfonyl-1-aza-1,3-butadiene ${ }^{10}$ and tetramethoxyethene ${ }^{11}$ followed by Lewis acid-promoted aromatization used to assemble the functionalized pyridine core. ${ }^{12}$ Additional key elements in the convergent approach include the use of an asymmetric anti-aldol reaction 
to install the $\mathrm{C} 9$ and $\mathrm{C} 10$ relative and absolute stereochemistry, a modified Julia olefination for formation of the C5-C6 trans double bond with convergent assemblage of the side chain, and a penultimate heterobenzylic Stille cross-coupling reaction of the pyridyl core with the fully elaborated side chain.

The key $N$-sulfonyl-1-aza-1,3-butadiene 7 was accessed through a two step sequence initiated by oxime formation of the ketone $4^{13}\left(\mathrm{NH}_{2} \mathrm{OH}-\mathrm{HCl}, \mathrm{EtOH}, 25^{\circ} \mathrm{C}, 18 \mathrm{~h}, 96 \%\right)$, Scheme 1. Treatment of the oxime 6 with $\mathrm{Et}_{3} \mathrm{~N}$ and methylsulfinyl chloride led to formation of the $O$ methanesulfinate and in situ homolytic rearrangement to give sulfonylimine $7\left(\mathrm{CH}_{3} \mathrm{SOCl}\right.$, $\left.\mathrm{Et}_{3} \mathrm{~N}, \mathrm{CH}_{2} \mathrm{Cl}_{2}, 0{ }^{\circ} \mathrm{C}, 20 \mathrm{~min}\right) .{ }^{14}$ Treatment of 7 with tetramethoxyethene ${ }^{11}(\mathbf{5}, 18 \mathrm{~h}$, toluene, $50{ }^{\circ} \mathrm{C}, 64 \%$ for 2 steps from 6 ) smoothly afforded the [4+2] cycloadduct 8 . Characteristic of the unusual reactivity of such electron-deficient $N$-sulfonylazadienes substituted with an additional C2 electron-withdrawing substituent, ${ }^{12 \mathrm{a}, \mathrm{b}}$ the Diels-Alder reaction of 7 with the electron-rich dienophile $\mathbf{5}$ was found to proceed at or near room temperature, even though $\mathbf{5}$ is tetrasubstituted and sterically demanding. Efforts to induce aromatization of $\mathbf{8}$ under a variety of basic conditions were not successful, whereas the use of the Lewis acid $\mathrm{BF}_{3} \cdot \mathrm{OEt}_{2}$ cleanly affected this transformation $\left(\mathrm{CH}_{2} \mathrm{Cl}_{2}, 0{ }^{\circ} \mathrm{C}, 1 \mathrm{~h}, 88 \%\right)$. Reduction of the ethyl ester 9 with DIBAL $\left(\mathrm{CH}_{2} \mathrm{Cl}_{2}, 0^{\circ} \mathrm{C}, 1 \mathrm{~h}, 92 \%\right)$ followed by protection of the resulting alcohol 10 as its TIPS ether provided 11 (TIPSCl, imidazole, DMF, $25^{\circ} \mathrm{C}, 18 \mathrm{~h}, 95 \%$ ). It was envisioned that directed lithiation of the remaining site on the pyridine ring followed by a borylation/oxidation sequence would permit incorporation of the remaining oxygen substituent at $\mathrm{C}^{\prime} .{ }^{15}$ Thus, treatment of 11 with excess base followed by trimethylborate ( 5 equiv of $\mathrm{BuLi}, 6$ equiv of $\mathrm{B}(\mathrm{OMe})_{3},-78$ ${ }^{\circ} \mathrm{C}, 1 \mathrm{~h}, 88 \%$ ), and oxidative cleavage of the resulting aryl boronate ester unexpectedly provided the $C$-silyated species 12 resulting from both the desired $\mathrm{C}^{\prime}$ ' hydroxylation and a competitive reverse Brook rearrangement of the benzylic TIPS ether under the strongly basic conditions.

16 The use of fewer equivalents of base results in the migrated, non-oxidized product, and the use of alternative silyl ether protecting groups (TBS and TBPDS) or the free alcohol 10 itself resulted in lower yields of the diol $\mathbf{1 3}$. The deprotection of $\mathbf{1 2}$ proceeded cleanly and, interestingly, through the $O$-silyated intermediate $\mathbf{S 1}^{16}\left(\mathrm{Bu}_{4} \mathrm{NF}\right.$, THF, $\left.30 \mathrm{~min}, 25^{\circ} \mathrm{C}, 80 \%\right)$ resulting from a Brook rearrangement, to give $\mathbf{1 3}\left(\mathrm{Bu}_{4} \mathrm{NF}, \mathrm{THF}, 36 \mathrm{~h}, 25^{\circ} \mathrm{C}, 96 \%\right.$ overall). Conversion of 13 to the heterobenzylic bromide $14\left(\mathrm{CBr}_{4}, \mathrm{PPh}_{3}, \mathrm{CH}_{2} \mathrm{Cl}_{2}, 25^{\circ} \mathrm{C}, 84 \%\right)$ provided a surprisingly stable partner for the Stille cross-coupling.

Synthesis of the side chain C2-C5 segment consisted of the preparation of the vinyl iodide 17 appropriately substituted for Julia-Kocienski olefination ${ }^{17}$ coupling with the C6-C13 side chain aldehyde 21, accessible from the known alcohol 20. ${ }^{6}$ This was accomplished through the reaction of alcohol $\mathbf{1 5}^{18}$ with 1-phenyl-1 $H$-tetrazole-5-thiol (PTSH) under Mitsunobu conditions (DEAD, $\mathrm{PPh}_{3}$, THF, $0{ }^{\circ} \mathrm{C}, 30 \mathrm{~min}, 71 \%$ ) to provide thioether 16 , which was cleanly oxidized to the sulfone 17 with ammonium molybdate $\left(\mathrm{H}_{2} \mathrm{O}_{2}\right.$, EtOH-THF, $\left.25^{\circ} \mathrm{C}, 6 \mathrm{~h}, 89 \%\right)$, Scheme $2 .{ }^{19}$ In order to address limitations in the reported synthesis of $\mathbf{1 8}$ (diastereomer separation), ${ }^{6}$ a recently disclosed and more effective asymmetric anti-aldol reaction was employed to access aldehyde 18,20 which was converted to alcohol 20 as described 6 and oxidized under Swern conditions to give $21\left((\mathrm{COCl})_{2}, \mathrm{DMSO},-78{ }^{\circ} \mathrm{C}, 99 \%\right)$, Scheme 3. A modified Julia coupling between $\mathbf{1 7}$ and $\mathbf{2 1}$ cleanly provided $\mathbf{2 2}$ (KHMDS, DME, $-78{ }^{\circ} \mathrm{C}, 18$ $\mathrm{h}, 60 \%$ ) with the trans alkene isomer as the only detected product. Lithium-halogen exchange of the vinyl iodide 22 upon treatment with $n$-BuLi, followed by treatment of the vinyllithium with tribuyltin chloride provided the vinyl stannane $\mathbf{2 3}$ for the Stille coupling with $\mathbf{1 4}$.

Coupling of 14 with 23 was found to require elevated temperatures, high loadings of the $\mathrm{Pd}_{2}(\mathrm{dba})_{3} /(t \mathrm{Bu})_{3} \mathrm{P}$ catalyst system employed by $\mathrm{Fu},{ }^{21}$ and $\mathrm{LiCl}$ as an additive to achieve good conversions, and when applied to the coupling provided 24 in superb conversions $\left(\mathrm{Pd}_{2}(\mathrm{dba})_{3},(t \mathrm{Bu})_{3} \mathrm{P}, \mathrm{LiCl}\right.$, dioxane, $\left.70^{\circ} \mathrm{C}, 18 \mathrm{~h}, 74 \%\right)$ without protection of the pyridyl phenol. A final deprotection of the TBS ether $\mathbf{2 4}\left(\mathrm{Bu}_{4} \mathrm{NF}, \mathrm{THF}, 50^{\circ} \mathrm{C}, 12 \mathrm{~h}, 93 \%\right)$ provided piericidin 
A1 identical in all respects with properties reported for the natural product (Scheme 3$)$. This included the sign and magnitude of the reported optical rotation for $\mathbf{1}\left([\alpha]_{\mathrm{D}}{ }^{25}+1.8(c 0.1\right.$, $\left.\mathrm{MeOH}) \mathrm{vs} \mathrm{lit}^{22}[\alpha]_{\mathrm{D}}{ }^{25}+1.0(c 0.1, \mathrm{MeOH})\right)$. However, the magnitude of this rotation value was viewed as insufficient to assign the absolute configuration of $\mathbf{1}$. In order to more confidently address this assignment, the conversion of $\mathbf{1}$ of piericidin B1 (2), which exhibits a larger optical rotation value, was also conducted. ${ }^{23}$ Thus, selective protection of the pyridine hydroxyl of 1 as its pivolate ester $25\left(\mathrm{PivCl}, \mathrm{HSO}_{4} \mathrm{NBu}_{4}\right.$, aqueous $5 \mathrm{~N} \mathrm{NaOH}-\mathrm{CH}_{2} \mathrm{Cl}_{2}, 25^{\circ}$ $\mathrm{C}, 92 \%)$, followed by $O$-methylation of the secondary alcohol $25\left(\mathrm{NaH}, \mathrm{MeI}, \mathrm{DMF}, 25^{\circ} \mathrm{C}, 1\right.$ $\mathrm{h}, 78 \%$ ), and finally pivolate hydrolysis of $\mathbf{2 6}\left(t-\mathrm{BuONa}, \mathrm{MeOH}, 60{ }^{\circ} \mathrm{C}, 3 \mathrm{~h}, 88 \%\right)$ provided 2. Synthetic piericidin B1 proved identical in all respects with properties reported for natural 2 , including its optical rotation $\left([\alpha]_{\mathrm{D}}^{25}-7.3(c 0.2, \mathrm{MeOH}) \mathrm{vs} \mathrm{lit}^{23}[\alpha]_{\mathrm{D}} 18-6.5(c 3.2, \mathrm{MeOH})\right)$, thereby further confirming the absolute configuration assignment for $\mathbf{1}$ and $\mathbf{2}$.

Throughout these studies and the handling of $1,2,12,13,14$, and 24 , only the 4hydroxypyridine tautomer, and not the 4-pyridone tautomer, was observed even in protic solvents. Provocatively, this suggests that the ability of $\mathbf{1}$ to bind and inhibit NADH-ubiquinone reductase (complex I) may result from mimicry of reduced coenzyme Q (hydroquinone) and rather than $\mathbf{3}$ itself. The synthesis of a series of analogues based on the natural products are underway and will probe such questions.

\section{Supplementary Material}

Refer to Web version on PubMed Central for supplementary material.

\section{Acknowledgements}

We gratefully acknowledge the financial support of the National Institutes of Health (CA 42056) and the Skaggs Institute for Chemical Biology. MJS is a Skaggs Fellow.

\section{References}

1. Takahashi N, Suzuki A, Tamura S. J Am Chem Soc 1965;87:2066. [PubMed: 14290282]

2. Esposti MD. Biochim Biophys Acta 1998;1364:222. [PubMed: 9593904]

3. Friedrich T, Van Heek P, Leif H, Ohnishi T, Forche E, Kunze B, Jansen R, Trowitzsch-Kienast W, Hofle G, Reichenbach H, Weiss H. Eur J Biochem 1994;219:691. [PubMed: 8307034]

4. Okun JG, Lummen P, Brandt U. J Biol Chem 1999;274:2625. [PubMed: 9915790]

5. Schmidtchen FP, Rapoport H. J Am Chem Soc 1977;99:7014. [PubMed: 561812]

6. Cox CM, Whiting DA. J Chem Soc Perkin Trans 1 1991:1901.

7. Takahashi N, Suzuki A, Kimura Y, Miyamoto S, Tamura S. Tetrahedron Lett 1967;8:1961. [PubMed: 6043699]

8. Yoshida S, Shiraishi S, Fujita K, Takahashi N. Tetrahedron Lett 1975;16:1863.

9. Jansen R, Hofle G. Tetrahedron Lett 1983;24:5485.

10. (a) Boger DL, Corbett WL, Wiggins JM. J Org Chem 1990;55:2999. (b) Boger DL, Corbett WL, Curran TT, Kasper AM. J Am Chem Soc 1991;113:1713. (c) Boger DL. Tetrahedron 1983;39:2869.Reviews:Boger DL. Chem Rev 1986;86:781.Boger DL. Chemtracts: Org Chem 1996;9:149.

11. Scheeren JW, Staps RJFM, Nivard RJF. Rec Trav Chim 1973;92:11.

12. (a) Boger DL, Cassidy KC, Nakahara S. J Am Chem Soc 1993;115:10733. (b) Boger DL, Hüter O, Mbiya K, Zhang M. J Am Chem Soc 1995;117:11839. (c) Boger DL, Hong J. J Am Chem Soc 1998;120:1218. (d) Boger DL, Blagg BSJ. Tetrahedron 2002;58:6343.

13. Rambaud M, Bakasse M, Duguay G, Villieras J. Synthesis 1988:564.

14. Brown C, Hudson RF, Record KAF. J Chem Soc Perkin Trans 2 1978:822.

15. Trecourt F, Mallet M, Mongin F, Queguiner G. J Org Chem 1994;59:6173. 
16. Wright A, West R. J Am Chem Soc 1974;96:3214.See Supporting Information for the isolation, structure, and characterization of $\mathrm{S} 1$.

17. Blakemore PR, Cole WJ, Kocienski PJ, Morley A. Synlett 1998:26.

18. Ndibwani A, Lamothe S, Guay D, Plante R, Soucy P, Goldstein S, Deslongchamps P. Can J Chem 1993;71:695.

19. Ahmed A, Hoegenauer EK, Enev VS, Hanbauer M, Kaehlig H, Ohler E, Mulzer J. J Org Chem 2003;68:3026. [PubMed: 12688769]

20. Nakao Y, Yoshida WY, Takada Y, Kimura J, Yang L, Mooberry SL, Scheuer PJ. J Nat Prod 2004;67:1332. [PubMed: 15332851]

21. Littke AF, Schwarz L, Fu GC. J Am Chem Soc 2002;124:6343. [PubMed: 12033863]

22. Urakawa A, Sasaki T, Yoshida K, Otani T, Lei Y, Yun W. J Antibiot 1996;49:1052. [PubMed: 8968401]

23. Takahashi N, Suzuki A, Kimura Y, Miyamoto S, Tamura S, Mitsui T, Fukami J. Agric Biol Chem 1968;32:1115. 

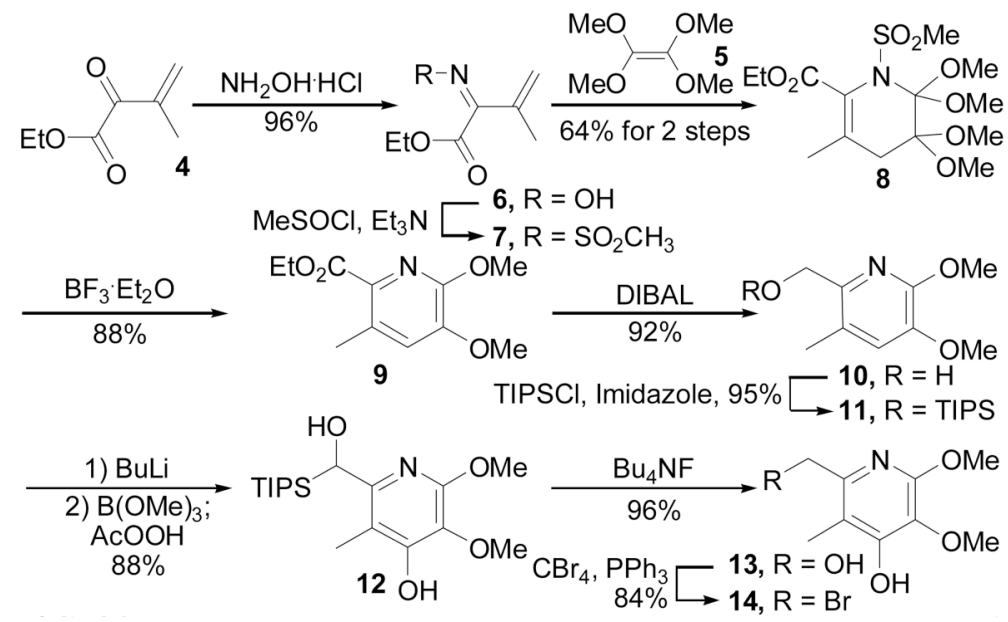

Scheme 1.

Synthesis of the Pyridine Core 


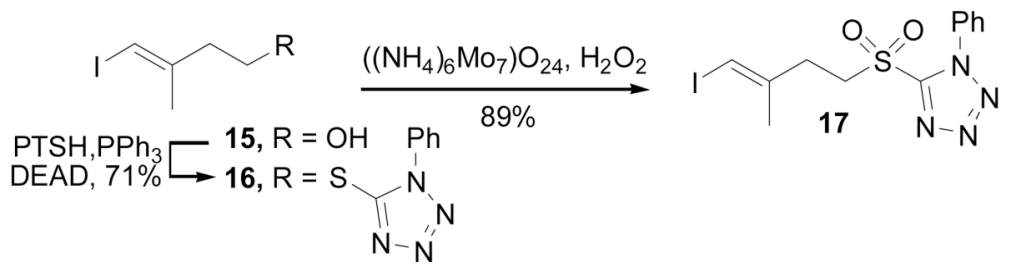

Scheme 2.

Synthesis of $\mathbf{1 7}$ 

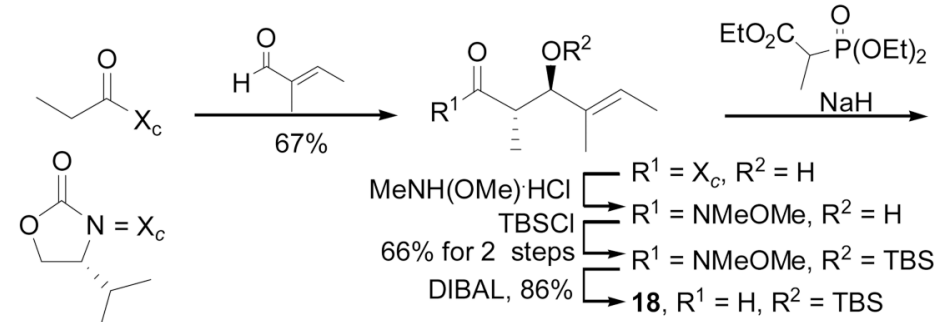

$\mathrm{MeNH}(\mathrm{OMe}) \cdot \mathrm{HCl}-\mathrm{R}^{1}=\mathrm{X}_{c}, \mathrm{R}^{2}=\mathrm{H}$

TBSCl $\longrightarrow \mathrm{R}^{1}=\mathrm{NMeOMe}, \mathrm{R}^{2}=\mathrm{H}$

$66 \%$ for 2 steps $\longrightarrow \mathrm{R}^{1}=\mathrm{NMeOMe}, \mathrm{R}^{2}=\mathrm{TBS}$

DIBAL, 86\% $\longrightarrow$ 18, $\mathrm{R}^{1}=\mathrm{H}, \mathrm{R}^{2}=$ TBS
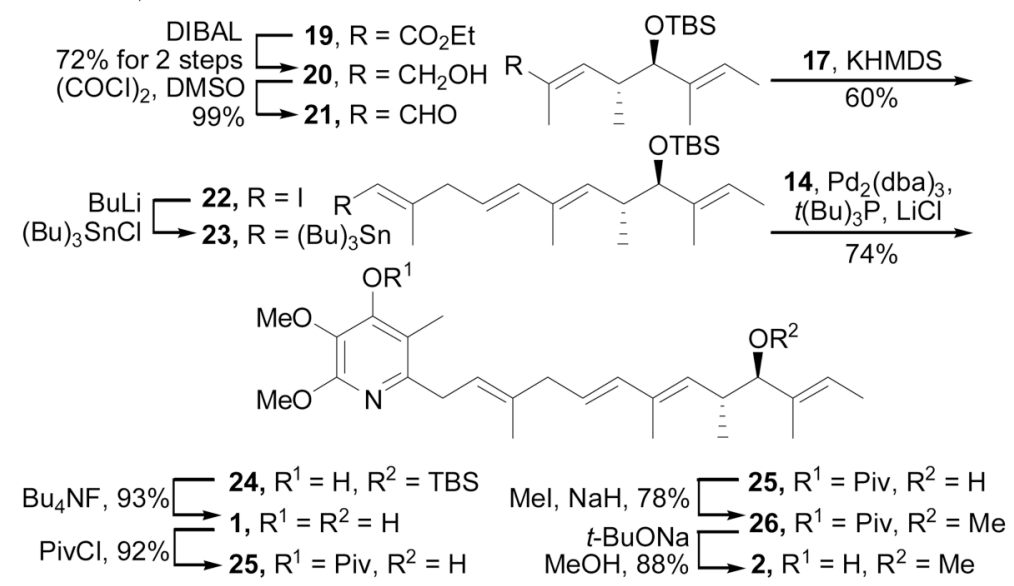

Scheme 3.

Synthesis of Piericidin A1 and B1 